\title{
Madura Cultural Identity Construction in Contemporary Indonesian Literature
}

\author{
S.Wasono ${ }^{1}$, S.R. Rusdiarti ${ }^{2}$, F.S. Nariswari ${ }^{3}$ \\ \{sunu_wasono@yahoo.com ${ }^{1}$ \} \\ Department of Literature, Faculty of Humanities, Universitas Indonesia
}

\begin{abstract}
The rapid advancement of digital technology and mass communication has had a tremendous impact on human life. In the literary context, this condition undoubtedly affects the writer's thought, orientation, and creativity. The thinning boundaries of local and global cultures due to the "unifying" of this universe allow the stimuli and thoughts of people living in certain areas to penetrate the boundaries of space. In literary works, the results may no longer represent the thoughts and culture in which the author was born and grew up. This research will focus on the construction of Madurese literary cultural identity in the context of contemporary Indonesian literature. By using ethnographic research methods and deepened by the concept of collective cultural identity from Stuart Hall, it was found that literary life in Madura moves dynamically in the tug of war between local and global cultural roots, and a new generation of Madurese writers offers a new cultural identity construction that is more laden with social criticism and humanity.
\end{abstract}

Keywords: cultural identity, identity construction, local cultures, Madurese literature

\section{Introduction}

As a large and pluralistic country, Indonesia has a very rich literature and is coloured by the local cultures from Aceh to Papua. Madura, is one of the local colours that has contributed a lot to the diversity of Indonesian literature. Global issues compete strongly with the locality and cultural identity of Madura to become a story. Themes of pilgrimage, ancestors, local rituals, or clashes with customs are issues that almost always appear in Madurese literature. These issues are then collided with national and global issues which will lead to dilemma problems for the figures. The thinning boundaries of local and global cultures due to the "unifying" of this universe allow the stimuli and thoughts of people living in certain areas to penetrate the boundaries of space. In literary works, the results may no longer represent the thoughts and culture in which the author was born and grew up.

There are not many studies on Madurese literature in the context of contemporary Indonesian literature. Several writings discuss traditional Madurese literature using the Madurese language. Azhar[1], Sari[2] and Irsyad[3] discuss the Madurese people and their basic character in traditional poetry, folk tales and short stories. Local wisdom in Madura is also discussed in the context of how it is applied in everyday life[4]. Meanwhile, Fatmawati[5] reveals the image of women and the thick patriarchal culture in Madura in a short story by Mahwi Air Tawar. In the context of world literature, studies of literature and cultural identity can be found in articles Kenyeres[6], Ojaide [7] and Sarikaya[8]. 
This research will focus on the construction of Madurese cultural identity in the context of contemporary Indonesian literature.

\section{Research Methods}

Data collection for this study used ethnographic methods involving deep interviews, directive interviews, and non-directive interviews with language activists and literary communities in Madura. We explore several literary texts using the close reading method to reveal their messages and views about Madurese culture. Furthermore, to describe the construction of their cultural identity, we use Stuart Hall's concept of cultural identity, which does not emphasize uniformity, but differences [9]. Cultural identity is not a matter a 'being' but of 'becoming', 'belonging as much to the future as it does to the past[10].

\section{Results and Discussion}

\subsection{Madurese Literature and Madurese Writers: About Definition}

A conversation about Madurese literature involving the Madurese literary community in a Focus Group Discussion with the Research Team in July 2020 revealed several interesting and essential things. The first discussion is about the definition of Madurese literature. Madura, first will be directly associated with the island of Madura. If Madurese literature is seen from a geographical perspective, it can be said that what is called Madurese Literature is a literary work originating from (the island) Madura. Madura can also be directly associated with the Madurese ethnicity.

Therefore, what is called Madurese literature is a literary work produced by people of Madurese ethnic background. In the perspective of language, there are those who argue that Madurese literature is a literary work that uses the Madurese language. This definition is in line with the thoughts of several researchers and literary actors in Madura, such as Iqbal Nurul Azhar, who in his article [11] clearly states that what is called Madurese literature is literature written in Madurese. Meanwhile, those who use Indonesian are included in the category of Indonesian literature.

In a broader view, thematically, all works that discuss Madura and its problems can be included in the category of Madurese Literature, although this seems to be somewhat less agreed upon by all representatives of the literary community who were present in the discussion. A temporary definition that might be concluded is: Madurese literature is literature created by writers who come from Madura or have a Madurese ethnic background, can use Madurese or Indonesian, and raise themes or topics related to Madurese culture and the complexity of its society.

\subsection{Madura in Indonesian Literature}

When we talk about Madura in Indonesian literature, a number of writers: Abdul Hadi WM, Zawawi Imron, Mahwi Air Tawar, Jamal D Rahman, ,just to mention some of them, immediately come to mind. These names come from Madura. However, the question is, is the Madurese cultural identity always present in their works? In some names, such as Zawawi Imron, Abdul Hadi WM, and Mahwi Air Tawar, perhaps local Madurese colors are present, however, in the works of Jamal d Rahman and perhaps a number of other writers from Madura, 
it seems that this is not the case. At least in Rubaiyat Matahari (2015) or Dekaplah Waktu Dekaplah Aku (2015), the local color of Madura is almost non-existent. Only one poem, "Sape Sono," shows its local Madurese content. The rest of the poems in the anthology carry various themes that do not show a direct connection with Madura.

Perhaps only Zawawi Imron, who in almost every poetry anthology he launches, presents Madura explicitly. In one of his poetry anthologies, there is the title Madura, I am your blood which shows how closely Zawawi Imron's poetry is to Madura. The anthology opens with the poem Ibu (Mother) which describes the narrator's love and pride for his mother and closes with the poem Madura, I am your blood. If the word Ibu in the poem is broadened to mean that it is interpreted not only as a figure who gives birth to a child, but as a symbol of the narrator's place, land of birth, or bloodshed, it is obvious that the poem shows the narrator's love for his homeland: Madura.

The closing poem Madura, I am your blood seems to reinforce what has been stated in the opening poems and other poems in the anthology, which almost all refer to Madura as a hometown ("Song of the Homeland") with various characteristics (nature, society, culture) that marks it. From the titles alone ("Season of Labuh", "Di Kebon Siwalan" "Young Sailors"), it can be seen how thick and strong the local color of Zawawi Imron's poems is. This can be seen, among other things, from the local diction (Madurese language) that adorns his poetry. Often footnotes are needed to help the reader understand the poetry he is writing. In Madura, I am your blood, there are not many footnotes, there are only six footnotes (pp. 5, 9, 14,15,39, 93), but in other collections of poetry, for example on Bantalku Ombak Selimutku Angin, there are so many footnotes accompanying it.

There are at least 26 words spread over a number of pages $(6,16,32,36,41,43,46,50,60$, $74,81,83,86,106)$ which should be explained in footnotes. Regional words can refer to the names of goods (dodot, saronen), plant names (nangger, gelagas, polai), people's names (Kiai Poleng), place names (Batotale), hero titles (Kudapanole), and circumstances (surup). Through a number of poetry anthologies by Zawawi, a picture of Madura which is associated with nature and its cultural richness can be seen. In other words, Madura, as imagined in the minds of many people, can be found in Zawawi Imron's poems collected in several books, at least in Madura, I am Your Blood and Bantalku Ombak Selimutku Angin.

The local Madurese culture seems to be found in the works of other Madurese writers as well. Two names should be mentioned here, Abdul Hadi WM and Mahwi Air Tawar. Abdul Hadi has published several collections of poetry. One of his monumental anthologies is the Anak Laut Anak Angin. This anthology is a compilation of several works by Abdul Hadi that have been published (Laut Belum Pasang, Potret Panjang Seorang Pengunjung Pantai Sanur, Cermin, dan Tergantung pada Angin). There are more than a hundred poems in this book. Unlike Zawawi Imron, Abdul Hadi seems to talk more about his experiences outside Madura. Apart from the Madurese background, other poems carry themes that seem to be related to Abdul Hadi WM's experiences in the various places he visited: Tawangmangu, Sarangan, Sanur Beach, Batimurung, Bombay, etc. Only the poem "Madura" which he placed at the very front explicitly depicted Madura.

What about other writers who also came from Madura, especially the post-Zawawi Imron and Abdulhadi WM generation? It has been explained in the previous section that there is Jamal D Rahman who seems to have written little about Madura either. However, there is another writer who is younger than Jamal D Rahman who makes Madura an object in his works, especially in his short stories. He is Mahwi Air Tawar. This writer has written two collections of short stories, Karapan Laut and Mata Blater which are full of local Madurese colors. The whole story in Karapan Laut and Mata Blater takes place and culture in the Madurese 
community. From the stories collected in the two books, it can be seen about the nature, culture and character of the Madurese people. The carok tradition, the relationship between santri and kyai, beliefs related to the grave, and the tradition of karapan sapi with all kinds of aspects related to it (mystical, incantations, shamanic practices) can be seen from his short stories.

Apart from writing short stories, Mahwi Air Tawar also wrote poetry. In contrast to his short stories which are full of local Madurese colors, his poetry shows the same tendency as the poems by Jamal d Rahman and Abdulhadi WM: they tend not to carry local Madurese colors. Mahwi Air Tawar's poetry is more likely to present his experiences outside Madura. In the poetry anthology Tanah Air Puisi which contains 31 poems, the local Madurese color does not appear dominantly.

Only a few poems ("Penyeberangan", "Madura", and "Tanah Air Karapan") explicitly mention the local Madurese colors. The remainder of the poems contain "recordings" of the narrator's experiences, reflections, and responses to various things. From the title and dedication placed under the titles of a number of his poems ("Ciuman Hamsad Rangkuti", "Bayangan Ibu D Kemalawati", "Crita dari Yeti AKKA", "Jalan Berkelok Raudal Tanjung Banua," "Dari Poso ke Sarajevo: Goenawan Mohamad", "Langgam Kayam”, "Perjumpaan dengan Chairil”), it appears that Mahwi Air Tawar — in writing poetry — is not too attached to Madura. He is more interested in responding to the works or ideas of other Indonesian writers, such as Umar Kayam, Hamsad Rangkuti, Goenawan Mohamad, Chairil Anwar, etc.

That is the brief description of some of the works of writers from Madura who wrote in Indonesian. If attention is widened by examining other writers who are younger than some of the authors mentioned, another picture is likely to be encountered. It is possible that the writers of the younger generation (the generation of the Reformation / millennial period) show a different tendency from the writers of the previous generation along with the dynamics of the times.

\subsection{Madura's Cultural Identity: New perspective, new construction}

The holding of the Bangkalan Literary Festival in 2018 in Bangkalan, Madura was a kind of eye opener that the language and literature community in Madura exists and continues to grow. There are literary activists who still have enthusiasm in the midst of the onslaught of media convergence. Various forums for discussion and appreciation of literature are being intensified in different media. In several literary competitions, both local and national levels, there were many young writers from Madura who participated and even received awards.

We had a dialogue with several young writers who were starting to be called the new generation of Madurese writers. Some that can be mentioned here are Mahwi Air Tawar, Mat Toyu, Royyan Julian, and Dwi Ratih Ramadhany. Each of these writers stated that they wanted to be seen as unique individuals and not to be seen as writers who merely reproduced the poetic regimes of the generations before them. They see customs and traditions as part of their identity, but they present them in their writings with new perspectives.

Mat Toyu, decided to continue writing in Madurese language. He even received a prize from the Rancage Cultural Foundation for his Madurese short story collection entitled Kerrong ka Omba. The jury praised the story in this book as depicting rural life in such a riveting way. His writings offer morals and kinship that are still respected in the village, respect for women and intimacy between generations. The narratives and dialogues in this book are arranged in a fluid language, showing that the authors also master good storytelling techniques. The award aroused Mat Toyu's optimism, that literature in madurese language still has a place in the hearts of readers and will continue to grow. 
The next writer, Royyan Julian chose to write in Indonesian. he is a prolific writer, as well as an activist and an academic. Royyan Julian stated that he did not want to be trapped in stereotypical and traditional Madurese. He wanted to critically raise the inner world of contemporary Madurese society and culture. In the short story Tandak, Royyan tries to describe Pali as a female character who works as a tandak dancer with a more critical perspective. Tandak or tayub is a traditional Madurese performing art centered on female dancers. Female dancers in Tandak performances often get a negative stigma as comfort women who tend to be used as male objects. Royyan asserted in his short story, that the dancers tandak is an artist and not just women who become sexual objects of men. This is also in line with the results of Saputra[12] and Susilowati's[13] researchs which uncovered the deconstruction and resistance of female characters in the short story Tandak. In his poetry anthology Biography of the Prophet's Body 2018) and the novel Tanjung Kemarau (2017), Royyan uses an ecocritical approach to address environmental issues in Madura.

The new generation of Madurese writers featured female writers, who had not appeared in the previous generation. The two female writers we will discuss below are Dwi Ratih Ramadhany and Muna Musyari. They both wrote in Indonesian but included many vocabularies typical of the Madura region. Both of them also tried to raise the position and problems of women in Madurese society, as well as gender issues[14]. Tradition, local wisdom, and Madurese identity are the main drivers of Muna's storyline.

For example, in the collection of Martabat Kematian short stories, the clash between tradition and modernity is an issue that is often discussed - even though in the end, it is modernity that "loses" when it comes to tradition that is deeply rooted in Madura. The main characters of Muna's works are mostly women who try to contest their fate and position of being marginalized. The main characters of Muna's works are mostly women who try to challenge the fate and position of being marginalized and eventually give up on the patriarchal traditions of their society. This is similar to the conclusion of M. Roifah and E. Hartanto's article discussing the portrait of women in Muna's short story [15]. Meanwhile, Dwi Ratih, from the start, wanted to provide space for women's perspectives, who had never been present or presented in the Madurese literature.

In Silsilah Duka, Dwi Ratih uses a women's perspective to present a discourse on women's bodies and sexuality. Compared to Muna who tends to defend tradition, Dwi Ratih is more willing to challenge traditions that are considered unfair to the roles and positions of women in Madurese society today

As Stuart Hall explains, collective cultural identity can lead to two directions. The first is the creation of a homogeneous collective identity, united in the awareness that we are the same and exist in one community[16]. Conversely, the second direction is more towards awareness if that identity never stops at one point, continues to change and responds to the challenges by changing times. Cultural identities such as these provide more room for change and diversity than fixation and uniformity[10]. In the context of this direction of cultural identity, the Madurese writers describe their respective cultural characteristics. It is this awareness of their different views on Madurese culture that makes their writing unique and directly voices the discourse of the inner world of the Madurese community and its problems more critically. 


\section{Conclusion}

Madurese culture and traditions have been a local color that has enriched Indonesian literature for a long time. The work of Madurese writers, both in madurese and in Indonesian language, is a proof that literature in Madura is very dynamic and has become part of its cultural identity. In the struggle between the modern and the traditional, the patriarchal and the feminist, the stereotypical and the critical, the new generation of Madurese writers chose to make their voices different and not fall into the dominant discourse of the old, established generation.

Writing Madura is constructing their cultural identity, as an effort to appreciate tradition, criticize today's social problems, and offer an ideal world perspective that becomes their hope for the future. The results of this study can be used to develop further studies about the aesthetic characteristics and perspectives of each author in seeing themselves as part of Madura.

\section{Acknowledgment}

This research was supported by the PUTI Proceedings 2020 (International Indexed Publication Research Grant) from the Directorate of Research and Community Service, Universitas Indonesia.

\section{References}

[1] I. N. Azhar, "Karakter Masysrakat Madura dalam Syair-Syair Lagu Daerah Madura," ATAVISME, 2009.

[2] I. N. Azhar and E. C. Sari H, "Prinsip-Prinsip Hidup Masyarakat Madura seperti Terkisah dalam Cerita Rakyatnya," ATAVISME, 2017.

[3] A. N. Irsyadi, "Madurese Typology and Characteristics Amelioration in Ahmad Sapardi's Short Story Pelean Klebun,” NOBEL J. Lit. Lang. Teach., 2018.

[4] A. S. Sadik, "Kearifan Lokal Dalam Sastra Madura Dan Aplikasinya Dalam Kehidupan Sehari-Hari," OKara, 2011.

[5] F. Fatmawati, "The Image of Madurese Women in 'Tandak' Short Story by Mahwi Air Tawar," NOBEL J. Lit. Lang. Teach., 2017.

[6] J. Kenyeres, "Manifestations of Hungarian Identity in Literature," Hungarian Cult. Stud., 2019.

[7] T. Ojaide, "Modern African Literature and Cultural Identity," Afr. Stud. Rev., vol. 35, no. 3, pp. 4357, 1992.

[8] D. SARIKAYA, "The Construction of Afro-Caribbean Cultural Identity in the Poetry of Linton Kwesi Johnson,” J. Caribb. Lit., vol. 7, no. 1, pp. 161-175, 2011.

[9] C. G. Voicu, "Stuart Hall Cultural identity and diaspora," Philobiblon, 2013.

[10] S. Hall, "Cultural identity and diaspora," in Diaspora and Visual Culture: Representing Africans and Jews, 2014.

[11] I. N. Azhar, "Talking About Madures Literature: from its potentials, its present reality, and its future," 2013.

[12] A. W. Saputra, "Dekonstruksi Sikap Hidup Tokoh Masyarakat Madura dalam Cerpen Tandak Karya Royyan Julian,” Wacana J. Bahasa, Seni, dan Pengajaran, 2017.

[13] E. Z. Susilowati., "Resistensi Perempuan Dalam Kumpulan Cerita Tandak Karya Royyan Julian (Teori Resistensi-James C.Scott)," J. Chem. Inf. Model., 2013.

[14] R. Julian, "MITOS KECANTIKAN DALAM CERPEN-CERPEN DWI RATIH RAMADHANY," J. Poet., 2016.

[15] M. Roifah and E. C. S. Hartanto, "The Portrayal of Madurese Women in Muna Masyari's Short Stories: 'Dukka Ronjangan,' 'Matinya Damar Kembang,' and 'Sortana,'” in SASTRA, BUDAYA, POLITIK, DAN KEBANGSAAN Prosiding Seminar Nasional Hiski Komisariat Surabaya, 2019.

[16] S. Hall, "Old and New Identities, Old and New Ethnicities," in Theories of Race and Racism, 2020. 